\title{
Clinical value of Pro-GRP and T lymphocyte subpopulation for the assessment of immune functions of lung cancer patients after DC-CIK biological therapy
}

\author{
LIJIE HE ${ }^{1}$, JING WANG ${ }^{2}$, DANDAN CHANG ${ }^{2},{\text { DANDAN } \mathrm{LV}^{3}, \mathrm{HAINA} \mathrm{LI}^{3} \text { and HEPING ZHANG }}^{3}$ \\ Departments of ${ }^{1} \mathrm{~T}$ Lymphocyte Subpopulation, ${ }^{2}$ Immunologic Function and ${ }^{3}$ Biological Therapy, \\ Tianjin Fifth Central Hospital, Tianjin 300450, P.R. China
}

Received December 15, 2016; Accepted July 11, 2017

DOI: $10.3892 /$ etm.2017.5520

\begin{abstract}
The present study investigated the aptness of assessing the levels of progastrin-releasing peptide (Pro-GRP) in addition to the $\mathrm{T}$ lymphocyte subpopulation in lung cancer patients prior to and after therapy for determining immune function. A total of 45 patients with lung cancer were recruited and stratified in to a non-small cell lung cancer (NSCLC) and an SCLC group. Prior to and after treatment by combined biological therapy comprising chemotherapy or chemoradiotherapy followed by three cycles of retransformation of autologous dendritic cells-cytokine-induced killer cells (DC-CIK), the peripheral blood was assessed for populations of $\mathrm{CD}^{+}, \mathrm{CD}^{+}, \mathrm{CD}^{+}$and regulatory $\mathrm{T}$ cells (Treg) by flow cytometry, and for the levels of pro-GRP, carcinoembryonic antigen, neuron-specific enolase and Cyfra 21-1. The results revealed that in NSCLC patients, $\mathrm{CD} 8^{+} \mathrm{T}$ lymphocytes and Treg populations were decreased, and that $\mathrm{CD}^{+}$and $\mathrm{CD}^{+}$ $\mathrm{T}$ lymphocytes as well as the $\mathrm{CD} 4^{+} / \mathrm{CD}^{+}$ratio were increased after therapy; in SCLC patients, $\mathrm{CD}^{+}, \mathrm{CD}^{+}$and $\mathrm{CD} 8^{+}$ $\mathrm{T}$ lymphocytes were increased, while Treg cells were decreased after treatment compared with those at baseline. In each group, Pro-GRP was decreased compared with that prior to treatment, and in the SCLC group only, an obvious negative correlation was identified between Pro-GRP and the T lymphocyte subpopulation. Furthermore, a significant correlation between Pro-GRP and Tregs was identified in each group. In conclusion, the present study revealed that the immune function of the patients was improved after biological therapy. The results suggested a significant correlation between Pro-GRP and the T lymphocyte subpopulation in SCLC patients. Detection of Pro-GRP may assist the early clinical diagnosis of SCLC
\end{abstract}

Correspondence to: Dr Heping Zhang, Department of Biological Therapy, Tianjin Fifth Central Hospital, 41 Zhejiang Road, Tianjin 300450, P.R. China

E-mail: 15620266287@163.com

Key words: progastrin-releasing peptide, T lymphocyte subpopulation, $\mathrm{T}$ regulatory cells, biological therapy, lung cancer and may also be used to assess the immune regulatory function of patients along with the $\mathrm{T}$ lymphocyte subpopulation. Biological therapy with retransformed autologous DC-CIK was indicated to enhance the specific elimination of tumor cells and improve the immune surveillance function in cancer patients, and also restrained the immune evasion of the tumor, leading to decreased Pro-GRP levels.

\section{Introduction}

Lung cancer is a type of malignant tumor, which has the highest morbidity and mortality worldwide (1). According to the World Health Organization, lung cancer was the most widespread and deadly cancer type in the world in 2015 (2). Due to aggravating air pollution and other problems, China has had 676, 000 newly diagnosed lung cancer cases and 565,000 associated mortalities in 2015 (2). Small cell lung cancer (SCLC) is highly aggressive, grows fast, has a tendency to metastasize to local lymph nodes, and features recurrence and distant metastasis in the early stage. Approximately $70 \%$ of lung cancer patients are in the late stage when the diagnosis is confirmed and most of them missed the opportunity to undergo conventional chemotherapy and radiotherapy; furthermore, associated adverse reactions are not acceptable for numerous patients and resistance is common. In the past 20 years, biological immunotherapy as a novel type of 'green therapy' has gradually attracted the attention of clinicians. Its principle is based on extracorporeal expansion of cells, including natural killer cells, dendritic cells (DCs) and cytokine-induced killer cells (CIKs), which are transplanted to stimulate the immune response of the body through a retransformation effect of the cells and its efficacy depends on the high killing activity of effector cells and the autologous immune system to fight tumor cells. The advantage of DC-CIK biological treatment is that the cells' high proliferation rate and cytotoxic activity against numerous cancer types, the simple and mild culture conditions, little adverse reactions and satisfactory patient compliance (3-5).

In an attempt to assess the efficacy of DC-CIK biological therapy as an adoptive immunotherapy in improving the immune function of lung cancer patients, the present study detected changes of immune function and tumor markers prior 
to and after treatment by collecting the blood of lung cancer patients prior to and one month after biological therapy. The application of DC-CIK is significant for the supportive treatment and life quality improvement of lung cancer patients and the present study provided a theoretical basis for the clinically normative application of DC-CIK cells in the treatment of lung cancer.

It is well known that SCLC cells produce gastrin-releasing peptide (GRP) and frequently have elevated levels of GRP. However, as GRP has a short half-life, Pro-GRP was assessed. Pro-GRP is a useful tumor marker with high sensitivity and specificity, which may be used for early diagnosis, and which may also reflect the progression of the disease and tumor response to treatment, as well as represent a prognostic tool in patients with SCLC (6); therefore, the present study examined Pro-GRP in lung cancer patients prior to and after treatment.

\section{Materials and methods}

Apparatus. The following apparatus was used in the present study: Electrochemical luminescence immunity analyzer Cobas E601 (Roche Diagnostics, Mannheim, Germany), FC500 flow cytometer (Beckman Coulter Co., Brea, CA, USA) and cell separator (COBE Spectra; Fresenius Kabi Ltd., Hong Kong, China). The detection kit for pro-GRP was from Roche Diagnostics GmbH (Mannheim, Germany; CEA.NSE. CYFR21-1).

Patients and samples. A total of 45 lung cancer patients, including 31 males and 14 females, were recruited at Tianjin Fifth Central Hospital (Tianjin, China) from September 2014 to August 2015. The patient age ranged from 43-86 years and the median age was 62 years. All patients were pathologically confirmed, including 13 patients with SCLC and 32 non-(N)SCLC patients. Clinical TNM staging of 45 patients with lung cancer was performed using TNM staging according to the 7th edition of the International Union Against Cancer (IUCC) (7). The clinical stage was stage III B for 18 cases and stage IV for 27 cases. The following exclusion criteria were applied to the present study: Acute infection, autoimmune diseases, a history of severe allergic reactions, liver and kidney function, poor overall condition and other fatal risk diseases, HIV positive, pregnancy or breast feeding. All of the patients were treated for lung cancer for the first time and did not have any immune-associated diseases or any other types of cancer, and had not received any radiation therapy, chemotherapy and immune therapy prior to detection. The protocol was approved by the Ethics Committee of Tianjin Fifth Central Hospital (Tianjin, China). The study was performed in accordance with the Code of Ethics of the Word Medical Association (Declaration of Helsinki), and all subjects provided written informed consent. A total of $5 \mathrm{ml}$ venous blood was collected from the elbow of overnight fasted patients prior to radiation therapy, chemical therapy and biological therapy. Pro-GRP was collected with separation gel coagulation-promoting tubes, and the T lymphocyte subpopulation and T-regulatory (Treg) cells were collected with EDTA-K2 anticoagulant. Samples were sent to the Laboratory Department of Tianjin Fifth Central Hospital (Tianjin, China) for analysis within $4 \mathrm{~h}$ after blood collection.
Chemotherapy and radiotherapy. Patients in the NSCLC group received three-dimensional conformal radiation therapy at $6 \mathrm{MV}$, administered as doses of $2 \mathrm{~Gy}$ applied 5 times a week to achieve a total dose of 60-70 Gy. Radiation was given at the beginning of synchronous chemotherapy with cisplatin $\left(75 \mathrm{mg} / \mathrm{m}^{2}\right)$ and paclitaxel $\left(135 \mathrm{mg} / \mathrm{m}^{2}\right)$, static drop $\mathrm{d} 1-\mathrm{d} 4$ (3 weeks per cycle for a total of 4 cycles). Radiotherapy was applied after the first cycle of chemotherapy. DC-CIK cell therapy was administered three times in total. The SCLC group received chemotherapy with etoposide $\left(100 \mathrm{mg} / \mathrm{m}^{2}\right)$ and cisplatin $\left(25 \mathrm{mg} / \mathrm{m}^{2}\right)$ static drop d1-d3 (3 weeks per cycle, 4-6 cycles) and DC-CIK cell therapy administered three times in total (Table I).

Laboratory analyses. The levels of Pro-GRP (cat. no. 3404883; Roche Diagnostics GmbH), carcinoembryonic antigen (CEA; cat. no. 3404885; Roche Diagnostics GmbH), neuron-specific enolase (NSE; cat. no. 3404881; Roche Diagnostics GmbH) and cytokeratin 19 fragment were assessed using ECLIA kits (CYFRA21-1; cat. no. 3404878; Roche Diagnostics GmbH).

Assessment of T lymphocyte subpopulation. A total of $10 \mu 1$ of four-color antibodies CD45/CD4/CD8/CD3 (CD45/CD4/CD8/CD3 flow cytometer detection kit; cat. no. 3403314; 1:100 dilution; Beckman Coulter, Inc., Brea, CA, USA) was added to flow cytometry tubes, mixed and incubated in the dark for 15-20 min. Subsequently, $100 \mu \mathrm{l}$ whole blood was added per tube, followed by addition of $500 \mu 1$ OptiLyse $\mathrm{C}$ hemolysin (Beckman Coulter, Inc.), mixing and incubation at $20-25^{\circ} \mathrm{C}$ in the dark for $10 \mathrm{~min}$. PBS (500 $\left.\mu \mathrm{l}\right)$ was added, followed by incubation at room temperature for $5 \mathrm{~min}$. Analysis was performed using flow cytometry within $2 \mathrm{~h}$.

Treg cell analysis. A total of $100 \mu 1$ venous blood was added to each flow cytometry tube, followed by addition of $20 \mu \mathrm{l}$ phycoerythrin-labelled anti-CD4 (CD4; cat. no. 00-5521; 1:200 dilution; Beckman Coulter, Inc.) and fluorescein isothiocyanate-labelled anti-CD25 (CD25; cat. no. 00-5523; 1:200 dilution; Beckman Coulter, Inc.) fluorescent monoclonal antibodies successively. After vortexing, samples were incubated at $20-25^{\circ} \mathrm{C}$ in the dark for $15-20 \mathrm{~min}$. Subsequently, $4 \mathrm{ml}$ cell lysis buffer was added, and the samples were vortexed and incubated at $20-25^{\circ} \mathrm{C}$ in the dark for $10 \mathrm{~min}$. Following centrifugation $\left(300 \mathrm{x} \mathrm{g}\right.$ for $5 \mathrm{~min}$ at $25^{\circ} \mathrm{C}$ ), the supernatant was collected. Lymphocyte cells were washed twice with $2 \mathrm{ml}$ PSB and subjected to flow cytometric analysis.

DC-CIK biological therapy. Depending on the height and weight of each patient, 4,000-5,000 $\mathrm{ml}$ peripheral blood was processed with a blood cell separator to collect and circulate the blood for four times. A total of $35 \mathrm{ml}$ peripheral blood, including $\sim 1 \times 10^{8}$ monocytes, was collected, followed by density gradient centrifugation $(400 \mathrm{x} \mathrm{g}$ for $30 \mathrm{~min}$ at $25^{\circ} \mathrm{C}$ ). Peripheral blood mononuclear cells were prepared under sterile conditions and cultured at $37^{\circ} \mathrm{C}$ in an incubator containing $5 \% \mathrm{CO}_{2}$ for $1-2 \mathrm{~h}$. Cells were suspended and collected, and culture medium (Beckman Coulter, Inc.) was added to adjust the concentration of the cells, which were then inoculated in a culture bottle and activated in vitro. After 24 h, CD3 monoclonal antibody, interleukin (IL)-2 and IL-1, 
Table I. Information on the chemotherapy and radiotherapy regimes of the lung cancer patients of the present study.

\begin{tabular}{lclcc}
\hline Cancer type & Patients (n) & Therapy & Cycles (n) & DC-CIK cell administrations (n) \\
\hline SCLC & 13 & EP chemotherapy & $4-6$ & 3 \\
NSCLC & 32 & TP chemotherapy + radiotherapy & 4 & 3 \\
\hline
\end{tabular}

NSCLC, non-small cell lung cancer; DC-CIK, dentritic cells-cytokine-induced killer cells; EP, etoposide + cisplatin; TP, cisplatin + paclitaxel.

Table II. Comparison of serum tumor markers between the SCLC and NSCLC groups before cancer treatment.

\begin{tabular}{lccccc}
\hline Groups & $\mathrm{n}$ & Pro-GRP $(\mathrm{pg} / \mathrm{ml})$ & CEA $(\mathrm{ng} / \mathrm{ml})$ & $\mathrm{NSE}(\mathrm{ng} / \mathrm{ml})$ & CYFR21-1 $(\mathrm{ng} / \mathrm{ml})$ \\
\hline SCLC & 13 & $1,943.71 \pm 208.53$ & $13.49 \pm 27.60$ & $80.83 \pm 10.57$ & $17.79 \pm 4.36$ \\
NSCLC & 32 & $47.69 \pm 24.11$ & $65.05 \pm 19.51$ & $17.79 \pm 4.36$ & $24.68 \pm 6.47$
\end{tabular}

Values are expressed as the mean \pm standard deviation. NSCLC, non-small cell lung cancer; Pro-GRP, progastrin-releasing peptide; CEA, carcinoembryonic antigen; NSE, neuron-specific enolase; CYFR, Cyfra.

(Miltenyi Biotec, Inc., Cambridge, MA, USA) was added to the culture medium. The culture medium was changed every 2 days and cultured $\left(37^{\circ} \mathrm{C}\right)$ for a total of $10-14$ days. Peripheral hematopoietic stem cells were expanded and DCs and CIKs were collected. The cell quantity was required to reach $>1 \times 10^{10}$ and the cell activity $>95 \%$. The cells were suspended in $100 \mathrm{ml}$ normal saline containing $20 \mathrm{~g} / \mathrm{l}$ human serum albumin and injected back into the patient's body once per week for a total of three times. A total of $1 \times 10^{9}$ cells was injected intravenously into the patient's body once per week for a total of three times. Peripheral venous blood was collected using the same method to assess Pro-GRP and T lymphocyte subpopulations after DC-CIK biological treatment for 1 month.

Statistical analysis. SPSS 19.0 software (IBM Corp., Armonk, NY, USA) was used for statistical analysis and values are expressed as the mean \pm standard deviation. Comparison between groups was performed by the comparison of parameters prior to and after biological therapy was assessed by a paired-samples t-test. The correlation analysis was performed using the Pearson method. $\mathrm{P}<0.05$ was considered to indicate a statistically significant difference.

\section{Results}

Levels of Pro-GRP, CEA, NSE and CYFR21-1 in lung cancer patients. As presented in Table II, Pro-GRP levels in the peripheral blood of patients from the SCLC and NSCLC groups were $1,943.71 \pm 208.53$ and $34.93 \pm 16.08 \mathrm{pg} / \mathrm{ml}$, respectively. Pro-GRP is highly expressed in SCLC patients and may even reach 5,000 pg/ml at times; the difference in Pro-GRP levels between the NSCLC and the SCLC groups was statistically significant. Furthermore, NSE and CYFRA21-1 levels in SCLC patients were higher than those in NSCLC patients, and the expression of CEA was not significantly different.

Comparison of Pro-GRP and T lymphocyte subpopulation levels prior to and after DC-CIK therapy. Peripheral blood was collected one week prior to and one month after DC-CIK biotherapy. As presented in Table III and Figs. 1 and 2, flow cytometry revealed that compared with prior to therapy, the amount of $\mathrm{CD}^{+}$and $\mathrm{CD}^{+}$cells as well as the $\mathrm{CD}^{+} / \mathrm{CD}^{+}$ ratio in the NSCLC group was obviously increased after therapy $(59.6 \pm 3.6$ vs. $62.3 \pm 3.8,31.7 \pm 2.8$ vs. $35.8 \pm 2.6$, and $1.2 \pm 0.2$ vs. $1.5 \pm 0.1 \%$, respectively), and the amount of $\mathrm{CD}^{+}$ cells $(27.3 \pm 3.6$ vs. $23.8 \pm 1.9 \%)$ and Treg cells $(15.0 \pm 3.9$ vs. $11.7 \pm 4.0 \%$ ) was obviously decreased. Notably, a previous finding indicated that an increase in the number of treg cells may be associated with the impairment of immune function in patients with lung cancer, which reduced the number of treg and immune suppression ability in addition to tumor volume (8). Furthermore, in the SCLC group, compared with prior to therapy, the amount of $\mathrm{CD}^{+}, \mathrm{CD} 4^{+}$and $\mathrm{CD}^{+}$cells as well as the $\mathrm{CD} 4^{+} / \mathrm{CD}^{+}$ratio were obviously increased $(49.4 \pm 12.1$ vs. $59.2 \pm 9.9,25.8 \pm 5.9$ vs. $30.9 \pm 5.4,23.8 \pm 6.2$ vs. $28.4 \pm 4.9$, and $1.1 \pm 0.1$ vs. $1.2 \pm 0.1 \%$, respectively), while the amount of Treg cells $(9.0 \pm 1.2$ vs. $7.6 \pm 1.1 \%)$ was obviously decreased. Compared with prior to therapy, Pro-GRP was significantly decreased after therapy.

Correlation between Pro-GRP and T lymphocyte subpopulation prior to and after therapy. As indicated in Table IV, the correlation coefficients between Pro-GRP and the $\mathrm{CD}^{+}$, $\mathrm{CD}^{+}$and $\mathrm{CD}^{+} \mathrm{T}$ lymphocyte subpopulations prior to therapy were $-0.94,-0.95$ and -0.92 , respectively, and the correlation coefficient between Pro-GRP and Treg cells was 0.84 in the SCLC group. There was also a significant correlation between Pro-GRP and Treg cells after therapy $(\mathrm{P}<0.05)$. In the NSCLC group, Pro-GRP was not correlated with the T lymphocyte subpopulations, but significantly correlated with the amount of Treg cells prior to as well as after treatment.

\section{Discussion}

Lung cancer is a malignant tumor type. Immune cells cannot effectively identify and kill tumor cells, and T lymphocytes 
Table III. Comparison of T lymphocyte subpopulations and Pro-GRP levels prior to and after DC-CIK therapy.

\begin{tabular}{|c|c|c|c|c|c|c|}
\hline \multirow[b]{2}{*}{ Parameter } & \multicolumn{3}{|c|}{ Non-small cell lung cancer } & \multicolumn{3}{|c|}{ Small cell lung cancer } \\
\hline & Prior to therapy & After therapy & t-value & Prior to therapy & After therapy & t-value \\
\hline \multicolumn{7}{|l|}{ T-lymphocytes } \\
\hline $\mathrm{CD}^{+}(\%)$ & $59.7 \pm 3.6$ & $62.3 \pm 3.8$ & $10.4^{\mathrm{a}}$ & $49.4 \pm 12.1$ & $59.2 \pm 9.9$ & $4.7^{\mathrm{a}}$ \\
\hline $\mathrm{CD}^{+}(\%)$ & $31.7 \pm 2.8$ & $35.8 \pm 2.6$ & $8.0^{\mathrm{a}}$ & $25.8 \pm 5.9$ & $30.9 \pm 5.4$ & $5.2^{\mathrm{a}}$ \\
\hline $\mathrm{CD}^{+}(\%)$ & $27.3 \pm 3.6$ & $23.8 \pm 1.9$ & $-7.0^{\mathrm{a}}$ & $23.8 \pm 6.2$ & $28.4 \pm 4.9$ & $3.9^{\mathrm{a}}$ \\
\hline $\mathrm{CD}^{+} / \mathrm{CD}^{+}$ & $1.2 \pm 0.2$ & $1.5 \pm 0.1$ & $8.4^{\mathrm{a}}$ & $1.1 \pm 0.1$ & $1.2 \pm 0.1$ & $1.2^{\mathrm{b}}$ \\
\hline Treg (\%) & $15.0 \pm 3.9$ & $11.7 \pm 4.0$ & $-6.1^{\mathrm{a}}$ & $9.0 \pm 1.2$ & $7.6 \pm 1.1$ & $-8.1^{\mathrm{a}}$ \\
\hline Pro-GRP (pg/ml) & $47.69 \pm 24.11$ & $37.13 \pm 15.23$ & $-3.9^{\mathrm{a}}$ & $1,943.71 \pm 208.53$ & $430.23 \pm 67.14$ & $-3.2^{\mathrm{b}}$ \\
\hline
\end{tabular}

${ }^{\mathrm{a}} \mathrm{P}<0.01,{ }^{\mathrm{b}} \mathrm{P}<0.05$. Values are expressed as the mean \pm standard deviation. NSCLC, non-small cell lung cancer; Pro-GRP, progastrin-releasing peptide; Treg, T-regulatory cells; DC-CIK, dentritic cells-cytokine-induced killer cells.
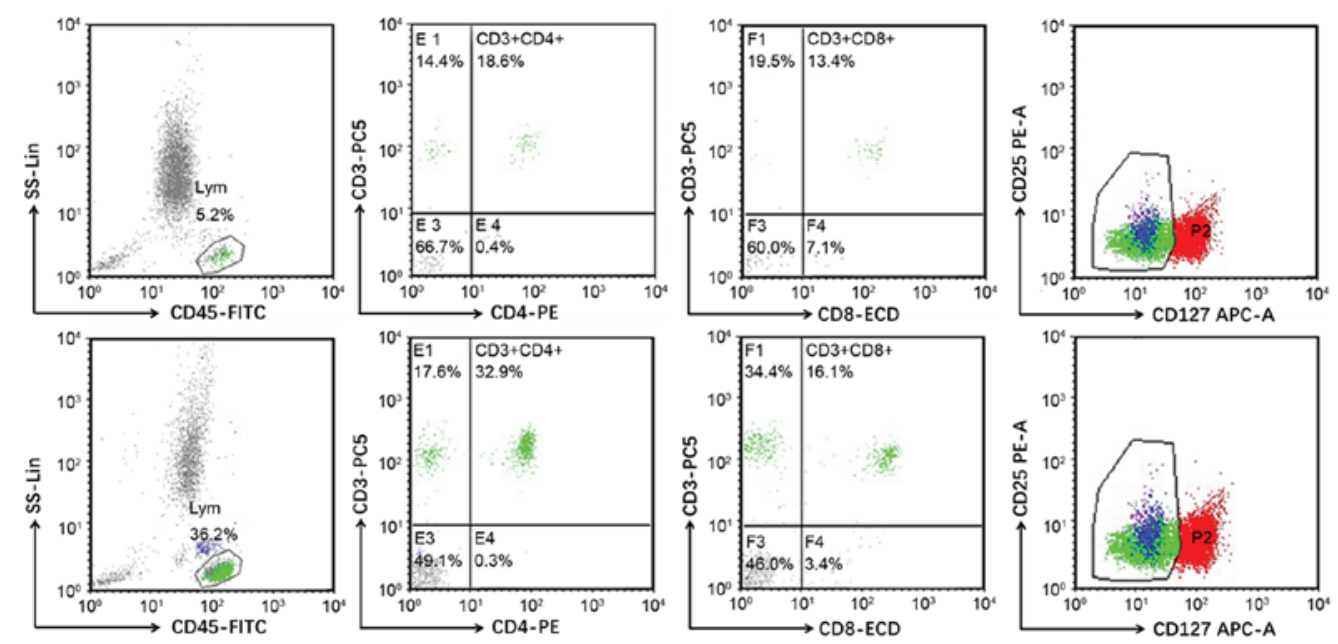

Figure 1. Flow cytometry dot plots displaying the T lymphocyte subpopulation prior to (upper panel) and 1 month after small cell lung cancer therapy (lower panel). Lym, lymphocytes.
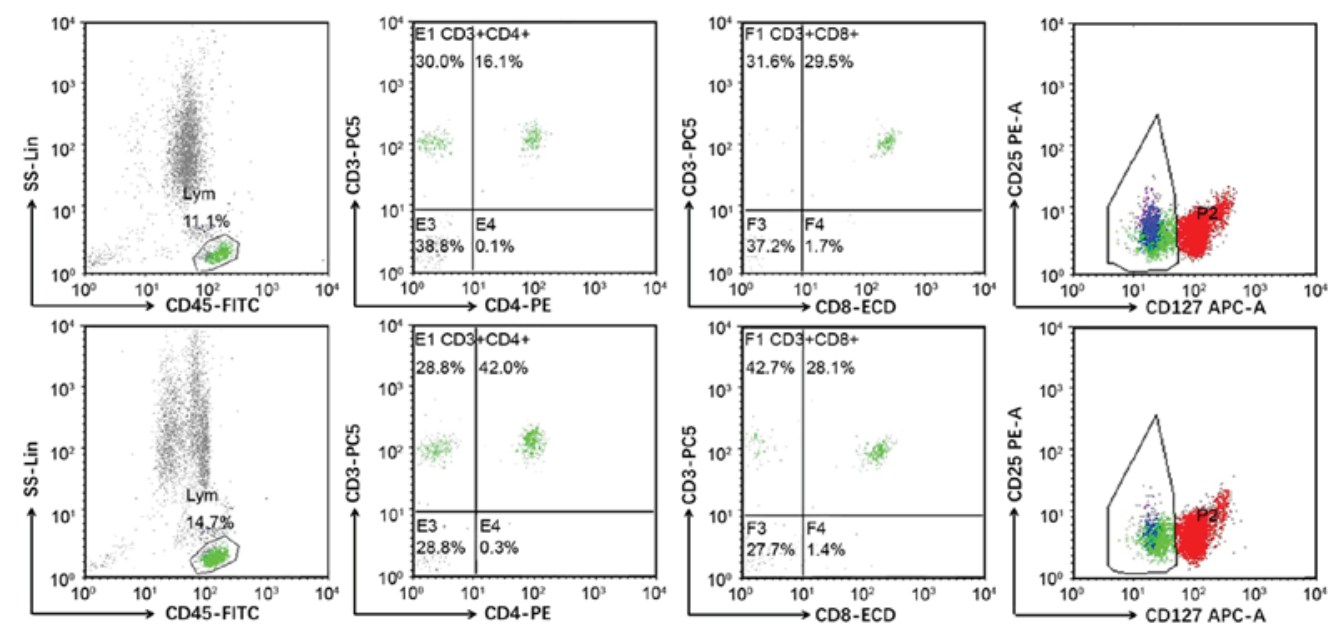

Figure 2. Flow cytometry dot plots displaying the T lymphocyte subpopulation prior to (upper panel) and 1 month after non-small cell lung cancer therapy (lower panel). Lym, lymphocytes.

are the key immunocompetent cells of the body that have important functions in immune monitoring, killing of target cells and immune adjustment (9). When the number of $\mathrm{T}$ lymphocytes in patients with lung cancer changes or 
Table IV. Pearson correlation coefficients of Pro-GRP and T lymphocyte subpopulations prior to and after therapy.

\begin{tabular}{lllll}
\hline Cancer type/time-point & $\mathrm{CD}^{+}$ & $\mathrm{CD}^{+}$ & $\mathrm{CD} 8^{+}$ & Treg \\
\hline NSCLC & & & & \\
$\quad$ Prior to therapy & -0.31 & -0.21 & -0.24 & $0.92^{\mathrm{a}}$ \\
After therapy & -0.21 & -0.34 & -0.09 & $0.87^{\mathrm{a}}$ \\
SCLC & & & & \\
$\quad \begin{array}{l}\text { Prior to therapy } \\
\text { After therapy }\end{array}$ & $-0.94^{\mathrm{a}}$ & $-0.95^{\mathrm{a}}$ & $-0.92^{\mathrm{a}}$ & $0.84^{\mathrm{a}}$ \\
\hline
\end{tabular}

${ }^{\mathrm{a}} \mathrm{P}<0.01,{ }^{\mathrm{b}} \mathrm{P}<0.05$ regarding the correlation between Pro-GRP levels and the $\mathrm{T}$ lymphocyte subpopulation at the respective time-point. Treg, T-regulatory cells; NSCLC, non-small cell lung cancer; Pro-GRP, progastrin-releasing peptide.

the $\mathrm{CD}^{+} / \mathrm{CD}^{+} \mathrm{T}$ cell ratio is abnormal, immune dysfunction is present. Long-term radiotherapy and chemotherapy may cause body immune function decline. Furthermore, DC-CIK biological treatment may improve these effects and the immune function of patients $(10) . \mathrm{CD}^{+}$cells reflect the overall cell immune state of organisms and are generally the sum of the number of $\mathrm{CD}^{+}$and $\mathrm{CD}^{+}$cells (11). Lung cancer patients have immune dysfunction; their cell immune functions are in a depressed state and their $\mathrm{CD}^{+}$cells are decreased (12). After biological therapy by DC-CIK cell retransformation, an obvious substation of lymphocytes is achieved. For instance, $\mathrm{CD}^{+}$and $\mathrm{CD}^{+} \mathrm{T}$ lymphocytes as well as the $\mathrm{CD}^{+} / \mathrm{CD}^{+}$ratio increase compared with prior to therapy (13). DC-CIK cell immune therapy enhances the excretion of the cell factors interferon (IFN)-g and IL-2 and the differentiation and proliferation of $\mathrm{CD}^{+}$cells (14). $\mathrm{CD}^{+}{ }^{+}$assists in inducing other lymphokines, including the excretion of IL-2, IFN-g, tumor necrosis factor- $\beta$ and other cell factors to kill tumor cells, and activate macrophages and natural killer cells to restrain the expression of tumor promoter genes to serve the purpose of inhibiting the proliferation and inducing the death of tumor cells as well as adjusting the functions of other immune cells in the body $(15,16)$. The increase of $\mathrm{CD}^{+}$and $\mathrm{CD} 4^{+} \mathrm{T}$ lymphocytes and the $\mathrm{CD} 4^{+} / \mathrm{CD}^{+}$ratio indicates that $\mathrm{DC}-\mathrm{CIK}$ has an immune adjustment function, leading to the improvement of anti-tumor immune levels and the recovery of the immune monitoring function in lung cancer patients.

Inhibiting $\mathrm{CD}^{+} \mathrm{T}$ lymphocytes directly exerts cytotoxic effects on antigen-presenting cells by causing excretion of cell factors including IL-4, IL-5, IL-10, IL-13, and restrains the production of antibodies by B lymphocytes through their unique network, which is a form of negative regulation (17). The increase of $\mathrm{CD}^{+}$cells is beneficial for the constant growth of a tumor (18). When the tumor evades the immune system, $\mathrm{CD} 4{ }^{+} \mathrm{CD} 25^{+}$Treg cells restrain the activation and proliferation of $\mathrm{CD}^{+}$cells by excreting IL-6 and IL-7 cell factors and inducing the activation of signal transducer and activator of transcription 4 . Treg cells highly express the adhesion molecules cytotoxic T-lymphocyte-associated protein 4 (CTLA-4) and forkhead box P3 (Foxp3) by combining with ligand B7 and activating the phosphoinositide-3 kinase signal channel, and restrain CD80 and CD86, which are costimulatory molecules of DCs, to prevent the latter from activating $\mathrm{T}$ cells to enhance the activation and proliferation of Treg cells and consequently their function. CTLA-4 and Foxp3 are transcription factors that are necessary and sufficient for induction of the immunosuppressive functions of Treg cells $(19,20)$. In the NSCLC group, $\mathrm{CD}^{+} \mathrm{T}$ lymphocytes and $\mathrm{CD} 4{ }^{+} \mathrm{CD} 25^{+}$Treg cells decreased after DC-CIK immune therapy compared with prior to DC-CIK immune therapy, resulting in a reduction of their immunosuppressive effect and recovery of the tumor cell killing function of T lymphocytes, which prevented the immune evasion of cancer cells in the tumor patients. However, compared with prior to therapy, $\mathrm{CD}^{+}$in the SCLC group increased. This difference is due to $\mathrm{CD}^{+}$cells being divided into cytotoxic $\mathrm{T}$ lymphocytes and inhabiting $\mathrm{T}$ lymphocytes, the latter of which have immunosuppressive functions, depending on whether they express CD28 (21). Therefore, $\mathrm{CD}^{+} \mathrm{T}$ cells have dual regulatory functions and their interaction is different between SCLC and NSCLC. SCLC has a higher malignant grade and the wide tumor cell infiltration leads to the stagnation of immune monitoring function; T lymphocytes basically lose their immune functions and cannot rapidly recover it to the normal level. The specific reasons for the differences in the levels of $\mathrm{CD}^{+} \mathrm{T}$ lymphocytes between SCLC and NSCLC require further elucidation.

The present study adopted a chemiluminescence-based method to assess Pro-GRP and NSE, revealing that in the SCLC group, Pro-GRP and NSE were higher than in the NSCLC group. A previous study proved that Pro-GRP is highly expressed in SCLC (10), and the specificity and sensitivity of Pro-GRP detection for SCLC diagnosis are higher than those of NSE $(22,23)$. In line with this, the present study also indicated that Pro-GRP is a specific tumor marker of SCLC that had a relatively high expression prior to therapy and exhibited on obvious decrease thereafter. A significant negative correlation between Pro-GRP and T lymphocytes was identified in the SCLC group. Pro-GRP was positively associated with Treg cells, indicating that the higher the levels of Pro-GRP are in SCLC patients, the poorer is their immune adjustment function and the stronger is their immune suppression. However, no obvious correlation between Pro-GRP and Treg cells was identified in the NSCLC group. These results indicated that Pro-GRP may be utilized as a clinical assessment index of immune function of SCLC patients and the decrease of Pro-GRP during treatment may indicate changes in their anti-tumor effect. To confirm the results of the present study, the sample size requires to be expanded in further studies.

DC-CIK cell retransformation biological therapy enhances the immune function in lung cancer patients and increases the capacity of specific killing of tumor cells by their autogenous immune cells. DC-CIK cell immune therapy improves the efficacy of traditional chemotherapy or chemoradiotherapy and enhances the anti-tumor effects (24-26). However, CIK therapy is currently not used for the conventional treatment of lung cancer due to the high individual cost of cell therapy; therefore, the cost of CIK therapy requires to be lowered for it to be provided to a large number of patients. 


\section{References}

1. Jemal A, Bray F, Center MM, Ferlay J, Ward E and Forman D: Global cancer statistics. CA Cancer J Clin 61: 69-90, 2011.

2. Chen W, Zheng R, Baade PD, Zhang S, Zeng H, Bray F, Jemal A, Yu XQ and He J: Cancer statistics in China, 2015. CA Cancer J Clin 66: 115-132, 2016.

3. Zhong R, Han B and Zhong H: A prospective study of the efficacy of a combination of autologous dendritic cells, cytokine-induced killer cells, and chemotherapy in advanced non-small cell lung cancer patients. Tumour Biol 35: 987-994, 2014.

4. Jin CG, Chen XQ, Li J, Wu ZP, Liu X and Wang XC: Moderating effects and maintenance of lung cancer cellular immune functions by CIK cell therapy. Asian Pac J Cancer Prev 14: 3587-3592, 2013.

5. Shi SB, Ma TH, Li CH and Tang XY: Effect of maintenance therapy with dendritic cells: Cytokine-induced killer cells in patients with advanced non-small cell lung cancer. Tumori 98 314-319, 2012.

6. Huang Z, Xu D, Zhang F, Ying Y and Song L: Pro-gastrin-releasing peptide and neuron-specific enolase: Useful predictors of response to chemotherapy and survival in patients with small cell lung cancer. Clin Transl Oncol 18: 1019-1025, 2016.

7. van Meerbeeck JP and Janssens A: The seventh tumour-nodemetastasis staging system for lung cancer: Sequel or prequel? EJC Suppl 11: 150-158, 2013.

8. Chen C, Chen D, Zhang Y, Chen Z, Zhu W, Zhang B, Wang Z and $\mathrm{Le} \mathrm{H}$ : Changes of $\mathrm{CD}^{+}{ }^{+} \mathrm{CD} 25^{+} \mathrm{FOXP} 3^{+}$and $\mathrm{CD}^{+} \mathrm{CD} 28$-regulatory $\mathrm{T}$ cells in non-small cell lung cancer patients undergoing surgery. Int Immunopharmacol 18: 255-261, 2014.

9. Mori A, Deola S, Xumerle L, Mijatovic V, Malerba G and Monsurrò V: Next generation sequencing: New tools in immunology and hematology. Blood Res 48: 242-249, 2013.

10. Cui Y, Yang X, Zhu W, Li J, Wu X and Pang Y: Immune response, clinical outcome and safety of dendritic cell vaccine in combination with cytokine-induced killed cell therapy in cancer patients. Oncol Lett 6: 537-541, 2013.

11. Kissick HT, Sanda MG, Dunn LK, Pellegrini KL, On ST, Noel JK and Arredouani MS: Androgens after T-cell immunity by inhibiting T-helper 1 differentiation. Proc Natl Acad Sci USA 111: 9887-9892, 2014.

12. Facciabene A, Motz GT and Coukos G: T-regulatory cells: Key players in tumor immune escape and angiogenesis. Cancer Res 72: 2162-2171, 2012.

13. Zhang Y, Huang S, Gong D, Qin Y and Shen Q: Programmed death-1 upregulation is correlated with dysfunction of tumor-infiltrating $\mathrm{CD}^{+} \mathrm{T}$ lymphocytes in human non-small cell lung cancer. Cell Mol lmmunol 7: 389-395, 2010.

14. Yan L, Wu M, Ba N, Wang LJ, Zhang HQ, Shi GY, Zhang ZS and Wang XJ: Efficacy of dendritic cell-cytokine-induced killer immunotherapy plus intensity-modulated radiation therapy in treating elderly patients with esophageal carcinoma. Genet Mol Res 14: 898-905, 2015.
15. Broderick L, Yokota SJ, Reineke J, Mathiowitz E, Stewart CC, Barcos M, Kelleher RJ Jr and Bankert RB: Human CD4 ${ }^{+}$effector memory $\mathrm{T}$ cell persisting in the microenvironment of lung cancer xenografts are activated by local delivery of IL-12 to proliferate, produce IFN-gamma, and eradicate tumor cells. J Immunol 174: 898-906, 2005.

16. Kin TY, Myoung HJ, Kim JH, Moon IS, Kim TG, Ahn WS and Sin JI: Both E7 and CpG-oligodeoxynucleotide are required for protective immunity against challenge with human papillomavirus 16 (E6/E7) immortalized tumor cells: Involvement of CD4 ${ }^{+}$ and $\mathrm{CD}^{+} \mathrm{T}$ cells in protection. Cancer Res 62: 7234-7240, 2002.

17. Kennedy RC, Shearer MH, Watts AM and Bright RK: CD4 ${ }^{+}$ $\mathrm{T}$ lymphocytes play a critical role in antibody production and tumor immunity against simian virus 40 large tumor antigen. Cancer Res 63: 1040-1045, 2003

18. Kissick HT, Sanda MG, Dunn LK, Pellegrini KL, On ST, Noel JK and Arredouani MS: Androgens alter T-cell immunity by inhibiting T-helper 1 differentiation. Proc Natl Acad Sci USA 111: 9887-9892, 2014.

19. Usó M, Jantus-Lewintre E, Gallach S, Sanmartin E, Martinez N, Blasco A, Guijarro R, Martorell M, Sirera R and Camps C: Association of Foxp3 expression with prognosis in resected non-small cell lung cancer (NSCLC). J Clin Oncol, 2011.

20. Grossi F, Salvi S, Merlo F, Margallo E, Boccardo S, Morabito A, Laurent S, Rijavec E, Barletta G, Genova C, et al: Evaluation of CTL antigen 4 (CTLA-4) expression as prognostic factor in non-small cell lung cancer (NSCLC). J Clin Oncol, 2011.

21. Filaci G, Fenoglio D, Fravega M, Ansaldo G, Borgonovo G, Traverso P, Villaggio B, Ferrera A, Kunkl A, Rizzi M, et al: CD8 ${ }^{+}$ CD28- $\mathrm{T}$ regulatory lymphocytes inhibiting $\mathrm{T}$ cell proliferative and cytotoxic functions infiltrate human cancers. J Immunol 179: 4323-4334, 2007

22. Inomata M, Hayashi R, Yamamoto A, Tokui K, Taka C, Okazawa S, Kambara K, Suzuki K, Ichikawa T, Yamada T, et al: Plasma neuron-specific enolase level as a prognostic marker in patients with non-small cell lung cancer receiving gefitinib. Mol Clin Oncol 3: 802-806, 2015.

23. Molina R, Augé JM, Bosch X, Escudero JM, Viñolas N, Marrades R, Ramírez J, Carcereny E and Filella X: Usefulness of serum tumor marker, including progastrin-releasing peptide, in patients with lung cancer: Correlation with histology. Tumour Biol 30: 121-129, 2009.

24. Nisman B, Biran H, Ramu N, Heching N, Barak V and Peretz T: The diagnostic and prognostic value of ProGRP in lung cancer. Anticancer Res 29: 4827-4832, 2009.

25. Li R, Wang C, Liu L, Du C, Cao S, Yu J, Wang SE, Hao X, Ren $\mathrm{X}$ and Li H: Autologous cytokine-induced killer cell immunotherapy in lung cancer: A phase II clinical study. Cancer Immunol Immunother 61: 2125-2133, 2012.

26. Li Z: Potential of human $\gamma \delta$ T cells for immunotherapy of osteosarcoma. Mol Biol Rep 40: 427-437, 2013. 